\title{
Children with Heart Conditions and Their Special Health Care Needs - United States, 2016
}

\author{
Meng-Yu Chen, MD ${ }^{1,2}$; Tiffany Riehle-Colarusso, $\mathrm{MD}^{2}$; Lorraine F. Yeung, MD²; Camille Smith, EdS² ; Sherry L. Farr, PhD 2
}

Children with heart conditions often use more health care services and specialized care than children without a heart condition (1); however, little is known about the number of U.S. children with heart conditions and their special health care needs. CDC used data from the 2016 National Survey of Children's Health (NSCH) to estimate the prevalence of heart conditions among U.S. children aged $0-17$ years, which indicated that $1.3 \%$ had a current heart condition and $1.1 \%$ had a past heart condition (representing approximately 900,000 and 755,000 children, respectively). Sixty percent and $40 \%$ of children with current and past heart conditions, respectively, had one or more special health care needs, compared with $18.7 \%$ of children without a heart condition (adjusted prevalence ratios $[\mathrm{aPRs}]=3.1$ and 2.1, respectively). Functional limitations were 6.3 times more common in children with current heart conditions (30.7\%) than in those without heart conditions (4.6\%). Among children with current heart conditions, males, children with lower family income, and children living in other than a two-parent household had an increased prevalence of special health care needs. These findings highlight the importance of developmental surveillance and screening for children with heart conditions and might inform public health resource planning.

Heart conditions in children can be congenital or acquired and range from asymptomatic to life-threatening. Congenital heart defects (CHDs) are the most common type of birth defect in the United States, affecting approximately $1 \%$ of live births (2). Children with CHDs often use more health care or educational services than do children without CHDs and might require specialized care $(1,3,4)$. Less is known about the prevalence or needs of children with acquired heart conditions. Previously, there have been no known U.S. population-based estimates of the number of children with heart conditions or their special health care needs.
$\mathrm{NSCH}$ is a population-based, nationally representative survey of parents or primary caregivers (parents) of noninstitutionalized U.S. children aged $0-17$ years. ${ }^{*} \mathrm{NSCH}$ asks parents about a selected child's health, health care access, and family characteristics. In 2016, a total of 364,150 households were

${ }^{*}$ https://mchb.hrsa.gov/data/national-surveys.

\section{INSIDE}

1050 Influenza Vaccination Coverage Among Health Care Personnel — United States, 2017-18 Influenza Season

1055 Influenza and Tdap Vaccination Coverage Among Pregnant Women — United States, April 2018

1060 Meningococcal Disease Surveillance in Men Who Have Sex with Men — United States, 2015-2016

1064 Multidrug-Resistant Aspergillus fumigatus Carrying Mutations Linked to Environmental Fungicide Exposure - Three States, 2010-2017

1068 Barriers to Receipt of Prenatal Tetanus Toxoid, Reduced Diphtheria Toxoid, and Acellular Pertussis Vaccine Among Mothers of Infants Aged $<4$ Months with Pertussis - California, 2016

1072 Current Tobacco Smoking, Quit Attempts, and Knowledge About Smoking Risks Among Persons Aged $\geq 15$ Years - Global Adult Tobacco Survey, 28 Countries, 2008-2016

1077 Notes from the Field: Blastomycosis Cases Occurring Outside of Regions with Known Endemicity - New York, 2007-2017

1079 QuickStats

Continuing Education examination available at https://www.cdc.gov/mmwr/cme/conted_info.html\#weekly.

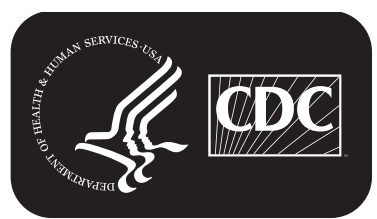

U.S. Department of Health and Human Services Centers for Disease Control and Prevention 
sampled; 138,009 (37.9\%) parents completed screener surveys, and 50,212 (36.4\%) of those completed topical surveys. The overall weighted response rate was $40.7 \% .^{\dagger}$

Parents were asked if they had ever been told by a health care provider that their child had a heart condition. Those who responded affirmatively were asked if their child currently had a heart condition. Children's heart condition status was categorized as "current," "past," or "none." Parents were also asked about their child's special health care needs using a standardized five-item screener that included 1) need for or use of medications (other than vitamins) prescribed by a doctor; 2) need for or use of medical care, mental health, or educational services beyond those of a similarly aged child (referred to as "average use"); 3) limitation in the child's ability to do things most children of the same age can do; 4) need for or use of specialized therapies such as physical, occupational, or speech therapy; and 5) need for or receipt of treatment or counseling for an emotional, behavioral, or developmental problem. If any special health care need was attributable to a medical, behavioral, or other health condition that had lasted, or was expected to last, 12 months or longer, the child was

\footnotetext{
${ }^{\dagger}$ https://www.census.gov/content/dam/Census/programs-surveys/nsch/tech-
} documentation/methodology/2016-NSCH-Methodology-Report.pdf. considered to have a special health care need. The questionnaire also inquired about 26 other health conditions. $\$$

The numbers and percentages of children with current, past, and no heart conditions were calculated. Chi-square tests were used to examine the differences in demographic characteristics (sex, age, race/ethnicity, family income as a percentage of the federal poverty level [FPL], highest parental education level achieved, health insurance type, and household structure); other health conditions; and special health care needs, by heart condition status. Marginal prediction approach to logistic regression was used to assess the association between heart condition status and one or more special health care needs, adjusted for demographic characteristics. Among children with a current heart condition, characteristics associated with having one or more special health care needs also were examined. All analyses were repeated excluding children with Down syndrome or other genetic conditions because these children's heart conditions might be related to the syndromes. All analyses included design parameters to account for complex

\footnotetext{
$\$$ Allergies, anxiety problems, arthritis, asthma, attention deficit disorder/attention deficit hyperactivity disorder, autism spectrum disorder, behavioral/conduct problems, blood disorders, brain injury, cerebral palsy, cystic fibrosis, depression, developmental delay, diabetes, Down syndrome, epilepsy/seizure disorder, headaches/migraines, hearing impairment, learning disability, mental retardation/intellectual disability, other genetic/inherited conditions, other mental health conditions, speech/language disorder, substance abuse, Tourette syndrome, and vision impairment.
}

The MMWR series of publications is published by the Center for Surveillance, Epidemiology, and Laboratory Services, Centers for Disease Control and Prevention (CDC), U.S. Department of Health and Human Services, Atlanta, GA 30329-4027.

Suggested citation: [Author names; first three, then et al., if more than six.] [Report title]. MMWR Morb Mortal Wkly Rep 2018;67:[inclusive page numbers].

\section{Centers for Disease Control and Prevention Robert R. Redfield, MD, Director \\ Anne Schuchat, MD, Principal Deputy Director \\ Leslie Dauphin, PhD, Acting Associate Director for Science \\ Joanne Cono, MD, ScM, Director, Office of Science Quality \\ Chesley L. Richards, MD, MPH, Deputy Director for Public Health Scientific Services}

William R. Mac Kenzie, MD, Acting Director, Center for Surveillance, Epidemiology, and Laboratory Services

MMWR Editorial and Production Staff (Weekly)
Charlotte K. Kent, PhD, MPH, Acting Editor in Chief, Executive Editor Jacqueline Gindler, MD, Editor

Mary Dott, MD, MPH, Online Editor

Teresa F. Rutledge, Managing Editor

Douglas W. Weatherwax, Lead Technical Writer-Editor

Glenn Damon, Soumya Dunworth, PhD, Teresa M. Hood, MS, Technical Writer-Editors
Martha F. Boyd, Lead Visual Information Specialist Maureen A. Leahy, Julia C. Martinroe, Stephen R. Spriggs, Tong Yang, Visual Information Specialists

Quang M. Doan, MBA, Phyllis H. King,

Terraye M. Starr, Moua Yang, Information Technology Specialists

\author{
MMWR Editorial Board \\ Timothy F. Jones, MD, Chairman \\ hyllis Meadows, PhD, MSN, RN \\ Jeff Niederdeppe, PhD
}

Matthew L. Boulton, MD, MPH

Virginia A. Caine, MD

Katherine Lyon Daniel, PhD

Jonathan E. Fielding, MD, MPH, MBA

David W. Fleming, MD
Patricia Quinlisk, MD, MPH

Patrick L. Remington, MD, MPH

Carlos Roig, MS, MA
William Schaffner, MD 
sampling and weights to generate population-based estimates of the numbers and prevalences of children with and without heart conditions.

Among the 50,212 children in the sample, 1,733 (3.5\%) were excluded from analysis because of missing information, including heart condition status (180), special health care needs (309), and demographic characteristics $(1,244)$. Excluded children were more commonly nonwhite, not privately insured, and living in households with lower income, lower parental education level, and other than two parents than were children who were not excluded ( $p<0.05$ for all). After weighting the data to represent the U.S. population of children $0-17$ years, an estimated 900,000 U.S. children (1.3\% of U.S. children; $95 \%$ confidence interval $[\mathrm{CI}]=1.1-1.5)$ had a current heart condition, 755,000 children $(1.1 \%$; 95\% CI $=0.9-1.3)$ had a past heart condition, and 68.1 million children $(97.6 \%$; $95 \%$ $\mathrm{CI}=97.3-97.9)$ had no heart condition.

Among children with current heart conditions, 58.3\% were male, $55.7 \%$ were non-Hispanic white, $21.5 \%$ had family income $<100 \%$ of FPL, $64.8 \%$ had at least one parent with higher than a high school education, $72.3 \%$ lived in a twoparent household, and $55.4 \%$ had private health insurance (Table 1). Demographic characteristics did not differ by heart condition status. Among children with current and past heart conditions, $67.2 \%$ and $60.5 \%$, respectively, had one or more other health conditions, compared with $46.7 \%$ of children with no heart condition $(\mathrm{p}<0.001)$.

Sixty percent of children with current heart conditions and $40.0 \%$ with past heart conditions had one or more special health care needs, compared with $18.7 \%$ of children without a heart condition (Table 2). Children with heart conditions most commonly needed or used prescription medicines (current $=42.8 \%$; past $=26.6 \%$ ) and had above average use of medical care, mental health, or educational services (current $=41.8 \%$; past $=23.9 \%$ ). Children with current or past heart conditions were 3.1 and 2.1 times more likely, respectively, to have one or more special health care needs than were children without a heart condition, with the

TABLE 1. Characteristics of children aged 0-17 years, by parent-reported heart condition status — National Survey of Children's Health, United States, 2016

\begin{tabular}{|c|c|c|c|c|c|c|c|}
\hline \multirow[b]{3}{*}{ Characteristic } & \multicolumn{6}{|c|}{ Heart condition status } & \multirow[b]{3}{*}{$\begin{array}{c}\text { Chi-square } \\
\text { p value }\end{array}$} \\
\hline & \multicolumn{2}{|c|}{ Current } & \multicolumn{2}{|c|}{ Past } & \multicolumn{2}{|c|}{ None } & \\
\hline & $\begin{array}{l}\text { Unweighted } \\
\text { no. }\end{array}$ & $\begin{array}{l}\text { Weighted \% } \\
\qquad(95 \% \mathrm{Cl})\end{array}$ & $\begin{array}{l}\text { Unweighted } \\
\text { no. }\end{array}$ & $\begin{array}{l}\text { Weighted \% } \\
\quad(95 \% \mathrm{Cl})\end{array}$ & $\begin{array}{l}\text { Unweighted } \\
\text { no. }\end{array}$ & $\begin{array}{l}\text { Weighted \% } \\
\quad(95 \% \mathrm{Cl})\end{array}$ & \\
\hline Total & 634 & - & 498 & - & 47,347 & - & - \\
\hline $\begin{array}{l}\text { Sex } \\
\text { Male } \\
\text { Female }\end{array}$ & $\begin{array}{l}356 \\
278\end{array}$ & $\begin{array}{l}58.3(50.0-66.1) \\
41.7(33.9-50.0)\end{array}$ & $\begin{array}{l}267 \\
231\end{array}$ & $\begin{array}{l}53.5(42.6-64.1) \\
46.5(35.9-57.4)\end{array}$ & $\begin{array}{l}24,189 \\
23,158\end{array}$ & $\begin{array}{l}50.8(49.8-51.8) \\
49.2(48.2-50.2)\end{array}$ & 0.17 \\
\hline $\begin{array}{l}\text { Age group (yrs) } \\
0-5 \\
6-11 \\
12-17\end{array}$ & $\begin{array}{l}185 \\
194 \\
255\end{array}$ & $\begin{array}{l}28.9(22.9-35.7) \\
44.0(35.9-52.4) \\
27.1(21.6-33.5)\end{array}$ & $\begin{array}{l}136 \\
144 \\
218\end{array}$ & $\begin{array}{l}27.9(20.5-36.7) \\
32.7(23.2-43.7) \\
39.5(29.1-50.9)\end{array}$ & $\begin{array}{l}13,717 \\
14,139 \\
19,491\end{array}$ & $\begin{array}{l}32.4(31.5-33.4) \\
33.9(32.9-34.9) \\
33.7(32.8-34.6)\end{array}$ & 0.16 \\
\hline $\begin{array}{l}\text { Race/Ethnicity } \\
\text { White, non-Hispanic } \\
\text { Other* }\end{array}$ & $\begin{array}{l}455 \\
179\end{array}$ & $\begin{array}{l}55.7(47.3-63.8) \\
44.3(36.2-52.7)\end{array}$ & $\begin{array}{l}356 \\
142\end{array}$ & $\begin{array}{l}52.0(41.0-62.8) \\
48.0(37.2-59.0)\end{array}$ & $\begin{array}{l}33,510 \\
13,837\end{array}$ & $\begin{array}{l}52.5(51.5-53.6) \\
47.5(46.4-48.5)\end{array}$ & 0.75 \\
\hline $\begin{array}{l}\text { Family income as a percenta } \\
<100 \% \\
100 \%-199 \% \\
200 \%-399 \% \\
\geq 400 \%\end{array}$ & $\begin{array}{c}\text { of federal pov } \\
72 \\
112 \\
208 \\
242\end{array}$ & $\begin{array}{l}\text { rty level }^{\dagger} \\
21.5(15.5-28.9) \\
27.4(19.6-36.8) \\
27.4(21.8-33.9) \\
23.7(18.7-29.7)\end{array}$ & $\begin{array}{r}58 \\
81 \\
169 \\
190\end{array}$ & $\begin{array}{l}28.7(17.6-43.3) \\
19.4(13.2-27.6) \\
27.6(20.6-36.0) \\
24.2(17.6-32.3)\end{array}$ & $\begin{array}{r}4,309 \\
7,375 \\
14,693 \\
20,970\end{array}$ & $\begin{array}{l}20.5(19.5-21.5) \\
21.9(21.0-22.9) \\
27.2(26.3-28.0) \\
30.4(29.6-31.2)\end{array}$ & 0.28 \\
\hline $\begin{array}{l}\text { Parental education level } \\
\text { High school graduate or less } \\
\text { More than high school } \\
\text { Household structure }\end{array}$ & $\begin{array}{l}107 \\
527\end{array}$ & $\begin{array}{l}35.2(26.9-44.6) \\
64.8(55.4-73.1)\end{array}$ & $\begin{array}{r}77 \\
421\end{array}$ & $\begin{array}{l}29.3(19.9-40.9) \\
70.7(59.1-80.1)\end{array}$ & $\begin{array}{r}6,772 \\
40,575\end{array}$ & $\begin{array}{l}28.4(27.3-29.6) \\
71.6(70.4-72.7)\end{array}$ & 0.38 \\
\hline $\begin{array}{l}\text { Two parents } \\
\text { Other }\end{array}$ & $\begin{array}{l}503 \\
131\end{array}$ & $\begin{array}{l}72.3(65.1-78.5) \\
27.7(21.5-34.9)\end{array}$ & $\begin{array}{l}393 \\
105\end{array}$ & $\begin{array}{l}77.6(69.6-83.9) \\
22.4(16.1-30.4)\end{array}$ & $\begin{array}{r}38,606 \\
8,741\end{array}$ & $\begin{array}{l}75.8(74.9-76.7) \\
24.2(23.3-25.1)\end{array}$ & 0.54 \\
\hline $\begin{array}{l}\text { Insurance type } \\
\text { Any private } \\
\text { Public, unspecified, or } \\
\text { uninsured }\end{array}$ & $\begin{array}{l}459 \\
173\end{array}$ & $\begin{array}{l}55.4(47.0-63.5) \\
44.6(36.5-53.0)\end{array}$ & $\begin{array}{l}354 \\
141\end{array}$ & $\begin{array}{l}50.7(39.9-61.5) \\
49.3(38.5-60.1)\end{array}$ & $\begin{array}{l}36,679 \\
10,544\end{array}$ & $\begin{array}{l}61.6(60.5-62.6) \\
38.4(37.4-39.5)\end{array}$ & 0.10 \\
\hline
\end{tabular}

Abbreviation: $\mathrm{Cl}=$ confidence interval.

* Includes Hispanic, non-Hispanic black, American Indian/Alaska Native, Native Hawaiian or Other Pacific Islander, and Asian.

† Based on the U.S. Department of Health and Human Services Poverty Guidelines.

$\S$ Highest education level among two parents or child's primary caregivers.

१ 129 had missing information on insurance type. 
TABLE 2. Percentage and adjusted prevalence ratio* of special health care needs ${ }^{\dagger}$ among children aged $0-17$ years, by parent-reported heart condition status - National Survey of Children's Health, United States, 2016

\begin{tabular}{|c|c|c|c|c|c|}
\hline \multirow[b]{3}{*}{ Special health care needs } & \multicolumn{5}{|c|}{ Heart condition status } \\
\hline & \multicolumn{2}{|c|}{ Current } & \multicolumn{2}{|c|}{ Past } & \multirow{2}{*}{$\frac{\text { None }}{\%(95 \% \mathrm{Cl})}$} \\
\hline & $\%(95 \% \mathrm{Cl})$ & $\mathrm{aPR}^{*}(95 \% \mathrm{Cl})$ & $\%(95 \% \mathrm{Cl})$ & $\mathrm{aPR}^{*}(95 \% \mathrm{Cl})$ & \\
\hline Has one or more special health care needs & $60.0(51.6-67.8)$ & $3.1(2.7-3.6)$ & $40.0(29.9-50.9)$ & $2.1(1.6-2.7)$ & $18.7(18.0-19.5)$ \\
\hline Needs or uses prescription medicines & $42.8(35.3-50.7)$ & $3.0(2.5-3.6)$ & $26.6(17.5-38.1)$ & $1.9(1.3-2.8)$ & $13.8(13.2-14.5)$ \\
\hline $\begin{array}{l}\text { Above average use of health care or educational } \\
\text { services }^{\S}\end{array}$ & $41.8(34.5-49.4)$ & $4.2(3.5-5.1)$ & $23.9(17.2-32.2)$ & $2.4(1.8-3.3)$ & $9.5(9.0-10.1)$ \\
\hline Has functional limitations & $30.7(24.3-38.0)$ & $6.3(5.0-8.1)$ & $17.4(11.5-25.5)$ & $3.7(2.4-5.6)$ & $4.6(4.1-5.0)$ \\
\hline $\begin{array}{l}\text { Needs or uses physical, occupational, or speech } \\
\text { therapies }\end{array}$ & $22.4(16.9-29.0)$ & $4.3(3.2-5.7)$ & $14.4(9.2-21.8)$ & $2.9(1.8-4.6)$ & $4.7(4.3-5.2)$ \\
\hline $\begin{array}{l}\text { Needs or receives treatment or counseling for } \\
\text { emotional, developmental or behavioral } \\
\text { conditions }\end{array}$ & $23.4(17.8-30.0)$ & $2.7(2.1-3.5)$ & $22.5(15.9-30.9)$ & $2.7(1.9-3.8)$ & $8.0(7.5-8.5)$ \\
\hline
\end{tabular}

Abbreviations: $\mathrm{aPR}=$ adjusted prevalence ratio; $\mathrm{Cl}=$ confidence interval.

* Prevalence ratio of special health care needs for current and past heart conditions versus no heart condition, adjusted for sex, age group, race/ethnicity, family income as a percentage of the federal poverty level, parental education level, and household structure.

† Based on having one or more of the following five conditions: needing or using prescription medicine; needing or using more medical care, mental health, or educational services than other children their age; having limitations in doing things, compared with other children their age; needing special therapy (e.g., physical, occupational, or speech therapy); or having an emotional, developmental, or behavioral problem in need of counseling or treatment. These conditions must be related to a medical, behavioral, or other health condition that has lasted or is expected to last 12 months or longer.

$\S$ Beyond those of a similarly aged child.

largest relative differences observed for functional limitations (current $\mathrm{aPR}=6.3 ; 95 \% \mathrm{CI}=5.0-8.1)$ (past $\mathrm{aPR}=3.7$; $95 \% \mathrm{CI}=2.4-5.6)$.

Among children with current heart conditions, an increased prevalence of special health care needs was observed among males $(\mathrm{aPR}=1.3 ; 95 \% \mathrm{CI}=1.1-1.7)$, children with family income $<100 \%$ of FPL $(\mathrm{aPR}=1.4 ; 95 \% \mathrm{CI}=1.0-2.0)$, and children living in other than a two-parent household $(\mathrm{aPR}=1.3 ; 95 \% \mathrm{CI}=1.0-1.6)$ (Table 3). Findings did not change substantially after excluding 1,650 children with Down syndrome or other genetic conditions, 181 (11\%) of whom had a heart condition.

\section{Discussion}

According to the $2016 \mathrm{NSCH}, 1.3 \%$ and $1.1 \%$ of U.S. children had a current or past heart condition, respectively. Because the specific types of heart conditions were unknown (i.e., congenital versus acquired), comparing current findings with published estimates of CHDs or acquired heart conditions is difficult. The birth prevalence of CHDs is nearly $1 \%$, and approximately 1 million U.S. children have CHDs (2). Although U.S. estimates of some acquired heart diseases such as those resulting from Kawasaki disease (5) and rheumatic heart disease $(\sigma)$ exist, the prevalence of other acquired heart conditions in children is unknown.

Children with CHDs are at increased risk for developmental disabilities and speech, motor, behavior, or learning problems (1), whereas the risk for children with acquired heart conditions has not been quantified. The higher prevalence of special health care needs among children with heart conditions, particularly
TABLE 3. Associations between selected demographic characteristics and special health care needs among children aged $0-17$ years who have a current heart condition - National Survey of Children's Health, United States, 2016

\begin{tabular}{|c|c|c|}
\hline \multirow[b]{2}{*}{ Characteristic } & $\begin{array}{l}\text { One or more special } \\
\text { health care needs }\end{array}$ & \multirow[b]{2}{*}{$\mathrm{aPR}^{*}(95 \% \mathrm{Cl})$} \\
\hline & Weighted \% (95\% Cl) & \\
\hline \multicolumn{3}{|l|}{ Sex } \\
\hline Male & $68.9(60.5-76.3)$ & $1.3(1.1-1.7)$ \\
\hline Female & $47.4(34.5-60.7)$ & Referent \\
\hline \multicolumn{3}{|l|}{ Age group (yrs) } \\
\hline $0-5$ & $57.8(45.9-68.9)$ & Referent \\
\hline $6-11$ & $58.5(42.7-72.7)$ & $1.0(0.7-1.2)$ \\
\hline $12-17$ & $64.4(53.4-74.4)$ & $1.1(0.9-1.3)$ \\
\hline \multicolumn{3}{|l|}{ Race/Ethnicity } \\
\hline White, non-Hispanic & $62.4(54.6-69.7)$ & Referent \\
\hline Other ${ }^{\dagger}$ & $56.8(41.3-71.1)$ & $0.9(0.7-1.1)$ \\
\hline \multicolumn{3}{|c|}{ Family income as a percentage of federal poverty level ${ }^{\S}$} \\
\hline$<100 \%$ & $80.5(67.3-89.3)$ & $1.4(1.0-2.0)$ \\
\hline $100 \%-199 \%$ & $52.8(32.6-72.2)$ & $1.0(0.7-1.5)$ \\
\hline $200 \%-399 \%$ & $59.5(47.8-70.2)$ & $1.1(0.9-1.5)$ \\
\hline$\geq 400 \%$ & $50.1(38.5-61.7)$ & Referent \\
\hline \multicolumn{3}{|l|}{ Parental education level $\left.\right|^{\pi}$} \\
\hline $\begin{array}{l}\text { High school graduate } \\
\text { or less }\end{array}$ & $62.0(41.6-78.9)$ & $1.0(0.8-1.3)$ \\
\hline More than high school & $58.8(51.6-65.7)$ & Referent \\
\hline \multicolumn{3}{|l|}{ Household structure } \\
\hline Two parents & $54.2(44.2-63.8)$ & Referent \\
\hline Other & $75.1(63.3-84.0)$ & $1.3(1.0-1.6)$ \\
\hline
\end{tabular}

Abbreviations: $\mathrm{aPR}=$ adjusted prevalence ratio. $\mathrm{Cl}=$ confidence interval.

* Prevalence ratios adjusted for sex, age group, race/ethnicity, family income, parental education level, and household structure.

† Includes Hispanic, non-Hispanic black, American Indian/Alaska Native, Native Hawaiian or Other Pacific Islander, and Asian.

$\S$ Based on the U.S. Department of Health and Human Services Poverty Guidelines.

१ Highest education level among two parents or child's primary caregivers. 


\section{Summary}

What is already known about this topic?

Children with heart conditions often need specialized care. Little is known about the number of U.S. children living with heart conditions and their special health care needs.

What is added by this report?

In 2016, 1.3\% of U.S. children had a current heart condition, and $1.1 \%$ had a past heart condition. Children with past and current heart conditions had higher prevalences of one or more special health care needs, compared with children without heart conditions.

What are the implications for public health practice?

These findings highlight the importance of developmental surveillance and screening among children with heart conditions for early identification and intervention and could inform public health resource planning.

functional limitations identified in this study, supports the American Academy of Pediatrics' guidance on developmental surveillance and screening for early identification and intervention (7), particularly for children with complex CHDs (e.g. single ventricle defects) (1).

Similar to the present findings among children with CHDs, male sex, lower family income, and other than two-parent household structure have been associated with special health care needs in the general pediatric population (8). The differences in the prevalence of special health care needs by sex, family income, and household structure could reflect a difference in health status or differential ascertainment. Associations between special health care needs and family income and household structure might be attributable to stress and financial issues associated with the child's health and treatment (9). More information is needed to know what resources might support families and benefit children.

The findings in this report are subject to at least five limitations. First, data are parent-reported and unconfirmed by medical records; however, according to findings from a study that used medical records to verify parental report of a diagnosis of autism (10), parental report of their child's medical history might be valid. Second, separate analyses for congenital, acquired, or other heart conditions could not be conducted because information on the type of heart condition was not available. Third, the composition of heart conditions relies on what the responding parent considered a "heart condition" or a "current heart condition," which might underestimate or overestimate the prevalence of heart conditions. Fourth, although the data were weighted for nonresponse, bias might remain. Finally, the temporality of special health care needs and family income or household structure is unknown.

These first population-based prevalence estimates of children with heart conditions and their special health care needs highlight the importance of guidelines for developmental surveillance and screening for early identification and intervention $(4,7)$. These estimates could inform national and state child health programs to ensure that children with heart conditions receive necessary services.

\section{Acknowledgment}

Karrie F. Downing.

Corresponding author: Sherry Farr, bwa0@cdc.gov, 404-498-3877.

${ }^{1}$ Epidemic Intelligence Service, CDC; ${ }^{2}$ Division of Congenital and Developmental Disorders, National Center on Birth Defects and Developmental Disabilities, CDC.

All authors have completed and submitted the ICMJE form for disclosure of potential conflicts of interest. No potential conflicts of interest were disclosed.

\section{References}

1. Marino BS, Lipkin PH, Newburger JW, et al. Neurodevelopmental outcomes in children with congenital heart disease: evaluation and management: a scientific statement from the American Heart Association. Circulation 2012;126:1143-72. https://doi.org/10.1161/ CIR.0b013e318265ee8a

2. Gilboa SM, Devine OJ, Kucik JE, et al. Congenital heart defects in the United States: estimating the magnitude of the affected population in 2010. Circulation 2016;134:101-9. https://doi.org/10.1161/ CIRCULATIONAHA.115.019307

3. Razzaghi H, Oster M, Reefhuis J. Long-term outcomes in children with congenital heart disease: National Health Interview Survey. J Pediatr 2015;166:119-24. https://doi.org/10.1016/j.jpeds.2014.09.006

4. Riehle-Colarusso T, Autry A, Razzaghi H, et al. Congenital heart defects and receipt of special education services. Pediatrics 2015;136:496-504. https://doi.org/10.1542/peds.2015-0259

5. McCrindle BW, Rowley AH, Newburger JW, et al.; American Heart Association Rheumatic Fever, Endocarditis, and Kawasaki Disease Committee of the Council on Cardiovascular Disease in the Young; Council on Cardiovascular and Stroke Nursing; Council on Cardiovascular Surgery and Anesthesia; Council on Epidemiology and Prevention. Diagnosis, treatment, and long-term management of Kawasaki disease: a scientific statement for health professionals from the American Heart Association. Circulation 2017;135:e927-99. https:// doi.org/10.1161/CIR.0000000000000484

6. Carapetis JR, Steer AC, Mulholland EK, Weber M. The global burden of group A streptococcal diseases. Lancet Infect Dis 2005;5:685-94. https://doi.org/10.1016/S1473-3099(05)70267-X

7. Council on Children With Disabilities; Section on Developmental Behavioral Pediatrics; Bright Futures Steering Committee; Medical Home Initiatives for Children With Special Needs Project Advisory Committee. Identifying infants and young children with developmental disorders in the medical home: an algorithm for developmental surveillance and screening. Pediatrics 2006;118:405-20. https://doi.org/10.1542/peds.2006-1231

8. Newacheck PW, Strickland B, Shonkoff JP, et al. An epidemiologic profile of children with special health care needs. Pediatrics 1998;102:117-23. https://doi.org/10.1542/peds.102.1.117

9. McClung N, Glidewell J, Farr SL. Financial burdens and mental health needs in families of children with congenital heart disease. Congenit Heart Dis 2018;4:554-62. https://doi.org//10.1111/chd.12605

10. Daniels AM, Rosenberg RE, Anderson C, Law JK, Marvin AR, Law PA. Verification of parent-report of child autism spectrum disorder diagnosis to a web-based autism registry. J Autism Dev Disord 2012;42:257-65. https://doi.org/10.1007/s10803-011-1236-7 